\title{
AREG wt Allele
}

National Cancer Institute

\section{Source}

National Cancer Institute. AREG wt Allele. NCI Thesaurus. Code C51416.

Human AREG wild-type allele is located within 4q13-q21 and is approximately $10 \mathrm{~kb}$ in length. This allele, which encodes amphiregulin protein, plays a role in the induction of mitosis and cellular growth. 